\title{
Strategi Perancangan Ashtāìgā Yoga Ashram di KaranganYaR, JaWA TengaH
}

\author{
Muhammad Satya Irfananda ${ }^{1}$, Mohamad Muqoffa ${ }^{2}$, Hardiyati ${ }^{3}$ \\ Program Studi Arsitektur, Fakultas Teknik, Universitas Sebelas Maret ${ }^{1}$ \\ satyairfananda@gmail.com \\ Program Studi Arsitektur, Fakultas Teknik, Universitas Sebelas Maret ${ }^{2}$ \\ Program Studi Arsitektur, Fakultas Teknik, Universitas Sebelas Maret ${ }^{3}$
}

\begin{abstract}
Ashtāngā Yoga Ashram adalah sebuah bangunan retret yang mewadahi latihan dan pendalaman ashtānga a yoga. Antusiasme pegiat yoga yang tinggi di Kabupaten Karanganyar mendasari dirancangnya bangunan ini. Artikel ini membahas pemikiran dasar perancangan tentang bagaimana praktik ashtāngā yoga mempengaruhi rancangan dari bangunan ini. Bangunan Ashtāngā Yoga Ashram dibutuhkan karena tidak terdapat banyak tempat di Indonesia di mana orang-orang dapat secara spesifik mempelajari laku ashtāing $\bar{a}$ yoga yang terdiri dari delapan elemen (yama, niyama, asana, pranayama, pratyahara, dharana, dhyana, samadhi). Setiap elemen dari ashtānga yoga tersebut memiliki tujuan khusus yang ingin dicapai. Berdasarkan karakter tersebut, setiap ruangan yang digunakan untuk berlatih pada bangunan ini harus didesain agar memiliki spesifikasi dan karakteristik khusus yang dapat mangokomodir kedelapan elemen dari ashtāng $\bar{a}$ yoga secara optimal. Didirikannya bangunan ini dapat menambah alternatif tempat bagi orang-orang untuk mendalami praktik yoga.
\end{abstract}

Kata-kunci: Ashtāingā Yoga, ashram, Karanganyar.

\section{PENDAHULUAN}

Setiap tahunnya, ribuan pegiat yoga dari berbagai daerah di Indonesia dan luar negeri berdatangan ke Kabupaten Karangnyar untuk berkumpul dan berlatih bersama. Alasan para pegiat yoga mendatangi Kabupaten Karanganyar, terutama Kecamatan Karangpandan, adalah karena tempat tersebut dinilai ideal untuk mendalami laku yoga dan meditasi. Jenis kegiatan yoga yang banyak dilakukan di daerah Karangpandan, khususnya di Candi Cetho dan Candi Sukuh adalah ashtāngā yoga. Para pegiat yoga dari berbagai tempat biasanya datang ke Karangpandan dan tinggal selama beberapa hari, bahkan minggu, untuk mendalami dan mempraktikkan laku ashtāing ā yoga.

Ashtāing à yoga adalah salah satu aliran yoga yang diperkenalkan oleh Bhagavān Patañjali melalui Yoga Sūtrāni Patañjali yang disusun sekitar tahun 400 SM (White, 2014). Disiplin yoga tersebut terdiri dari delapan laku, yaitu yama, disiplin atau pengendalian diri yang berfokus pada hubungan horizontal sesama manusia dan lingkungan; niyama atau pedoman perilaku untuk membina hubungan vertikal dengan Tuhan dan alam semesta; āsana atau postur-postur, gerakan-gerakan untuk memperbaiki sikap hidup; prāṇāyāma atau pengaturan energi atau aliran kehidupan lewat pengendalian, latihan pernapasan; pratyāhāra atau menarik diri dari segala impuls kelima panca indera; dhāraṇa , fokus, atau kontemplasi; dhyāna atau meditasi; dan samādhi, keseimbangan diri, kesadaran, kemanunggalan, atau pencerahan (Krishna, 2015). Samādhi adalah sebuah keadaan yang secara otomatis tercapai apabila kita melakukan ketujuh laku sebelumnya dengan baik.

Ashtāingā Yoga Ashram dirasa perlu untuk dibangun karena ashtāing $\bar{a}$ yoga adalah sebuah disiplin yoga yang sangat kompleks dan menyeluruh, sehingga pada era kontemporer 
ini membutuhkan tempat khusus untuk mendalaminya. Ashram adalah tempat pertapaan atau tempat pendalaman dalam tradisi Yoga (Swahananda, 1990).

Perhatian utama dari perancangan ini adalah tiap kegiatan pembelajaran di Ashtāing $\bar{a}$ Yoga Ashram memiliki karakteristik tersendiri. Sehingga, wadah bagi setiap kegiatan tersebut juga harus dapat mengakomodir setiap laku. Suasana wadah bagi kegiatan yoga harus disesuaikan dengan karakter dari laku tersebut. Oleh karena itu, dalam perumusan konsep perencanaan dan perancangan didasarkan pada instisari dari delapan laku (ashtāng $\bar{a}$ ) terebut, untuk menghasilkan sebuah wadah yang ideal.

\section{METODE}

Penyusunan konsep perancangan Ashtāing $\bar{a}$ Yoga Ashram dilakukan melalui beberapa tahapan yang saling berhubungan. Tahap paling awal dalam pekerjaan merumuskan sebuah konsep perencanaan dan perancangan adalah menentukan obyek yang akan dirancang serta gagasan utama yang menjadi latar belakang dipilihnya obyek tersebut. Setiap tahapan dilakukan sampai menghasilkan produk akhir berupa konsep perencanaan dan perancangan.

Gagasan utama merupakan gagasan awal yang didapat dari suatu fenomena yang ingin disampaikan. Pengungkapan gagasan utama berkembang dengan adanya studi pustaka dan eksplorasi. Pada tahap ini, gagasan utama yang diperoleh dari suatu fenomena disusun menjadi beberapa kutub-kutub. Dalam hal ini kutub-kutub yang menjadi materi ekplorasi adalah mengenai ashtāingā yoga, ashram, dan Kabupaten Karanganyar

Setelah menentukan kutub-kutub dari obyek rancang bangun, langkah selanjutnya adalah melakukan eksplorasi awal terhadap kutubkutub tersebut. Eksplorasi awal berupa kajian secara umum yang dilakukan dengan cara mengumpulkan data-data yang tersedia. Datadata yang diperoleh melalui proses eksplorasi awal akan memberikan gambaran mengenai kualitas dari obyek rancang bangun yang ingin diraih. Permasalahan yang harus dipecahkan tersebut disebut permasalahan desain. Dari permasalahan desain, dapat dirumuskan persoalan desain, berupa kriteria-kriteria lebih spesifik yang harus dipenuhi untuk menjawab permasalahan yang lebih besar.

Setelah mempelajari karakter kegiatan dari setiap laku ashtānga a yoga serta tapak dari obyek rancang bangun, muncul kriteria wadah yang akan direncanakan. Kriteria-kriteria tersebut kemudian dikelompokkan menurut aspek arsitekturalnya. Kriteria-kriteria arsitektural tersebut akan memudahkan dalam proses analisis.

Analisis perencanaan dan analisis perancangan dilakukan berdasarkan kriteria-kriteria arsitektural yang muncul dari tahap selanjutnya. Analisis dilakukan dengan cara menjabarkan kriteria-kriteria tersebut, untuk kemudian menyusun strategi dalam mencapainya. Strategi yang disusun dapat berupa alternatif-alternatif desain, yang kemudian dikerucutkan berdasarkan pada kondisi dan batasan-batasan dari obyek rancang bangun.

Tahap terakhir adalah presentasi akhir dari perencanaan dan perancangan ashtāngga yoga Ashram, yang merupakan sintesa dari analisis yang telah dilakukan sebelumnya. Produk akhir yang disajikan meliputi strategi desain, gambar desain utama, dan gambar desain pelengkap. Dalam proses perumusan konsep perencanaan dan perancangan Ashtāingā Yoga Ashram, kedelapan laku dari ashtāingā yoga menjadi dasar pertimbangan utama.

\section{ANALISIS}

Berikut ini merupakan analisis untuk menentukan konsep perencanaan dan perancangan sebagai arahan dalam proses desain. Analisis kebutuhan ruang diperoleh dengan melakukan identifikasi pelaku dan kegiatan pelaku. Berdasarkan hasil identifikasi pelaku dan pola kegiatannya melalui tinjauan preseden, maka dapat diidentifikasi ruangruang yang dibutuhkan (Tabel 1). Konsep peruangan Ashtāingā Yoga Ashram didasarkan pada tingkat kesakralan dari kegiatan yang dilakukan. Pengunjung pertama datang ke area 
yang lebih terbuka untuk melakukan kegiatankegiatan bersama, menuju ke ruang-ruang dengan suasana yang lebih sakral untuk kegiatan-kegiatan yang bersifat meditatif (Gambar 1).

Tabel 1. Kebutuhan Ruang.

\begin{tabular}{|c|c|}
\hline Kelompok Kegiatan & Kebutuhan Ruang \\
\hline Laku Ashtāngā Yoga & 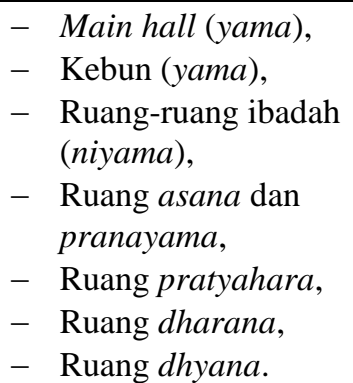 \\
\hline Operasional & $\begin{array}{l}\text { - Kantor pengelola, } \\
\text { - Dapur. }\end{array}$ \\
\hline Istirahat & 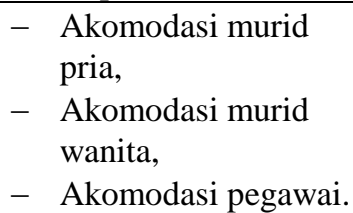 \\
\hline Kegiatan Pendukung & $\begin{array}{l}\text { - Perpustakaan, } \\
\text { - Kamar mandi, } \\
\text { - Pos keamanan, } \\
\text { - Garasi, } \\
\text { - } \text { Gudang }\end{array}$ \\
\hline
\end{tabular}

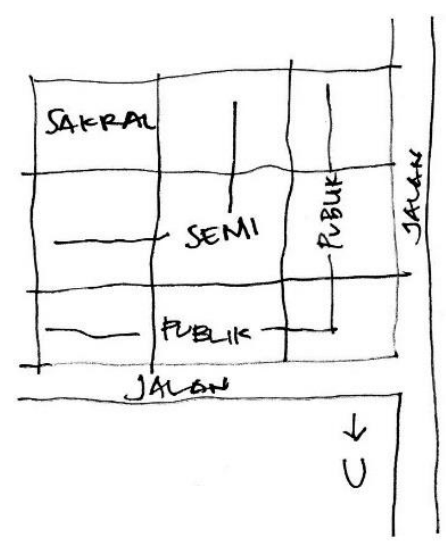

Gambar 1. Zonasi Tapak Berdasarkan Tingkat Kesakralan Kegiatan.

Setiap kegiatan dari ashtāng $\bar{a}$ yoga membutuhkan karakter dan atmosfer wadah yang khusus agar dapat dilakukan secara optimal. Ruang-ruang khusus yang akan dirancang kemudian dianalisis satu persatu untuk menentukan karakter dan spesifikasi ruang tersebut. Langkah pertama adalah menganalisis setiap laku dari ashtāngā yoga beserta karakter kegiatannya. Langkah berikutnya adalah mencari elemen-elemen yang berpengaruh terhadap pembentukan atmosfer ruang. Kedua hasil analisa tersebut kemudian disintesa untuk menjadi konsep perencanaan setiap ruang yang mewadahi setiap laku.

Konsep wadah laku yang pertama, yama atau pengendalian diri, yaitu menciptakan atmosfer yang mendukung interaksi positif antar sesama pelaku yoga. Pendalaman yama ini akan banyak dilakukan di main hall. Ruang yang dirancang bersifat luas dan lapang, serta terang (Gambar 2). Ruang main hall digunakan untuk berbagai macam kegiatan bersama-sama, seperti diskusi, sosialisasi, hingga makan bersama. Ruang main hall di lantai atas berhubungan dengan dapur umum di lantai bawah, dimana pengunjung dan staf dapat bersama-sama mempersiapkan makanan yang akan dimakan bersama. Tidak terdapat furnitur main hall, sehingga fungsi ruangan menjadi fleksibel.

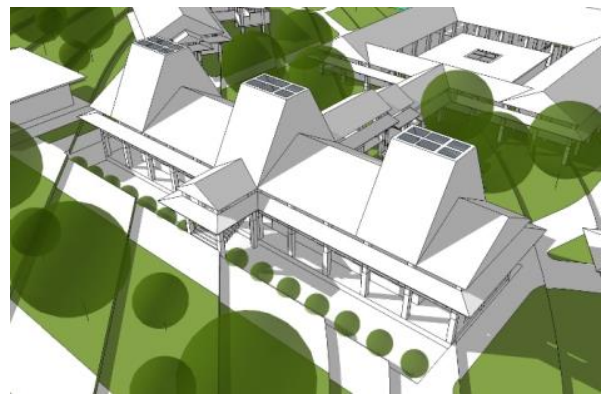

Gambar 2. Bangunan Main Hall.

Wadah laku yang kedua, niyama atau hubungan vertikal dengan Tuhan dan alam semesta dirancang untuk memiliki suasana yang tenang dan khusyuk. Terdapat dua ruang, yaitu musholla yang dapat digunakan oleh pengunjung ashram serta masyarakat sekitar, serta ruang doa umum yang dapat digunakan oleh pengunjung yang tidak beragama Islam (Gambar 3). Pada kedua ruangan, pencahayaan dibuat temaram. Pada siang hari, satu-satunya sumber pencahayaan adalah dari skylight yang terdapat pada atap, yang memendarkan cahaya temaram. Terdapat elemen buffer yang melindungi ruangan dari kebisingan. Tanaman perdu menyaring suara-suara bising, 
sedangkan elemen air yang mengalir menghasilkan suara gemericik yang mengalihkan perhatian dari keributan di luar.

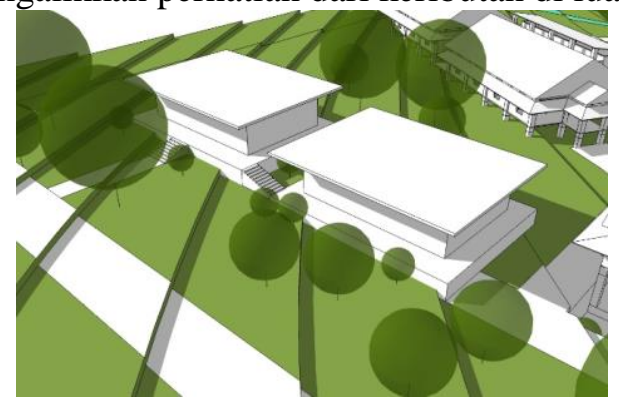

Gambar 3. Bangunan Wadah Niyama.

Wadah laku yang pertama dan kedua dipisah dari wadah laku yang lainnya. Hal ini dikarenakan wadah laku yang pertama dan kedua sering diakses oleh pengunjung, sehingga dapat mengganggu kegiatan yang dilakukan pada wadah laku-laku berikutnya. Untuk mencapai wadah laku ketiga hingga ketujuh, pengunjung harus melewati sebuah jembatan (Gambar 4). Jembatan ini dikelilingi oleh pepohonan yang membentuk suasana hening. Jembatan ini sekaligus menjadi ruang transisi antara ruang yang lebih ramai dengan ruang yang lebih hening.

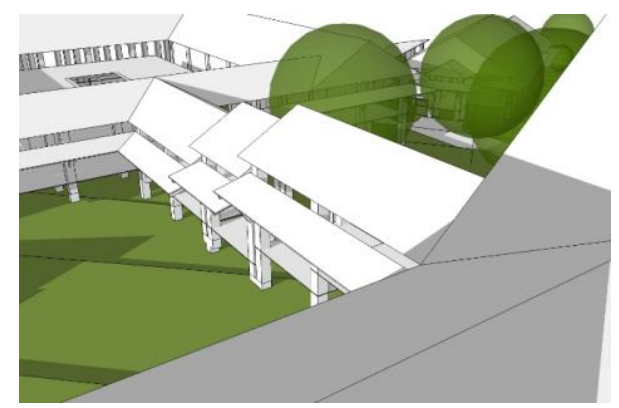

Gambar 4. Jembatan Penghubung.

Ruangan āsana atau pengaturan postur tubuh, menciptakan atmosfer yang mendukung kegiatan olah tubuh yang optimal, didesain dengan langit-langit yang tinggi agar menghindarkan dari kesan penuh dan sesak ketika melakukan gerakan-gerakan olah tubuh. Ruang memiliki kesan luas dan tanpa partisi, agar murid-murid dapat dengan leluasa memperhatikan peragaan gerakan dari instruktur (Gambar 5). Instruktur mengambil posisi di sisi ruang yang panjang, agar dapat lebih mudah terlihat oleh murid-murid.

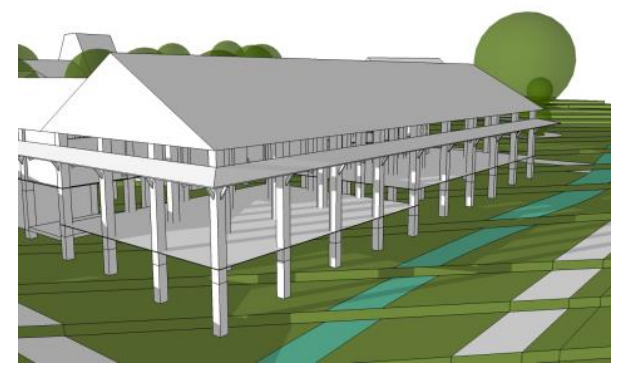

Gambar 5. Bangunan Wadah Asana.

Konsep wadah laku yang keempat, prānāyāma atau pengaturan napas, adalah menciptakan atmosfer yang menenangkan pikiran dan kelegaan ketika mengatur prāṇa. Ruangan didesain agar dapat merespon aliran angin yang optimal. Udara yang melewati ruangan harus dapat dengan mudah keluar dan masuk, namun memiliki kecepatan yang optimal agar tidak mengganggu kenyamanan. Ruangan diberi kisi-kisi yang dapat dibuka-tutup di kedua sisinya untuk mengatur aliran udara (Gambar 6). Selain itu, vegetasi di sekitar ruangan membantu menyaring udara yang berhembus. Orientasi ruangan adalah menghadap arah timur-barat, merespon arah aliran angin dari lereng Gunung Lawu.

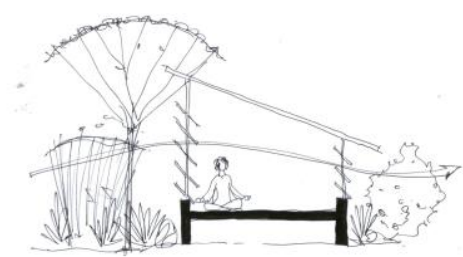

Gambar 6. Konsep Wadah Prāṇāyāma.

Laku pratyāhāra atau pelepasan impuls duniawi membutuhkan atmosfer yang mendukung pengendalian panca indera. Latihan dilakukan di bawah naungan pohon trembesi yang sudah berdiri di tapak selama puluhan tahun (Gambar 7). Dengan pembatas ruang yang minim, impuls-impuls dari lingkungan sekitar akan merangsang panca indera dan memaksa orang-orang untuk menahannya. 


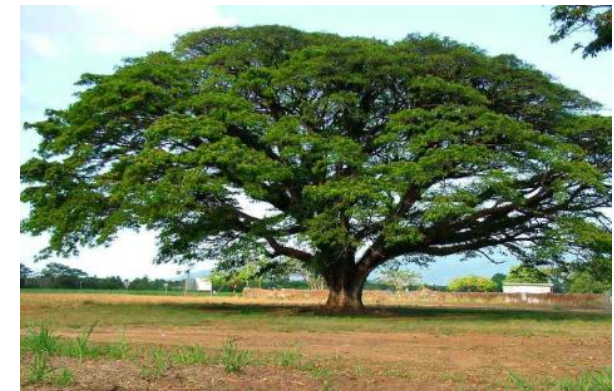

Gambar 7. Pohon Trembesi Pada Tapak.

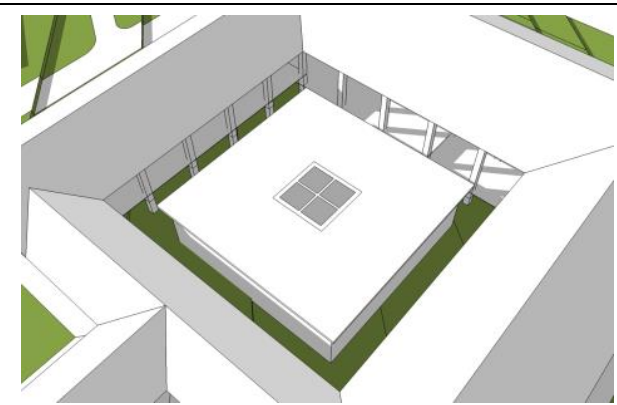

Gambar 9. Wadah Dhyana.
Konsep wadah laku yang keenam, dhāraṇā atau konsentrasi, adalah menciptakan atmosfer tenang yang mendukung pengendalian pikiran. Para murid berlatih dengan menatap sebuah lilin di ruangan yang gelap (Gambar 8). Ruangan dijaga agar tetap gelap dengan cara menutup lubang-lubang ventilasi. Walaupun terselubung, lubang ventilasi memiliki ukuran yang optimal agar asap dari lilin dapat dengan leluasa keluar. Agar tidak mengganggu konsentrasi, para murid duduk membentuk lingkaran dengan membelakangi satu sama lain, menghadap ke dinding.

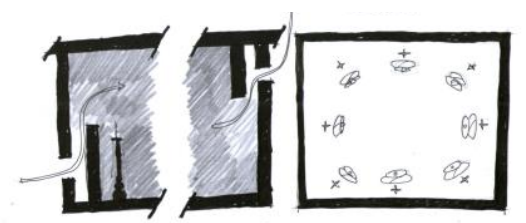

Gambar 8. Konsep Ruang Dharana.

Konsep wadah laku yang ketujuh, dhyāna atau kontemplasi, adalah menciptakan atmosfer yang mendukung kegiatan meditatif dengan tujuan menyatukan badan, pikiran, dan lingkungan sekitar. Ruangan ini dirancang dengan bentuk yang sesederhana mungkin, berupa kubus persegi yang melambangkan kestabilan yang dirasakan ketika mencapai samadhi (Gambar 9). Ruangan seolah-olah mengambang di atas kolam, seperti bunga teratai yang mengambang di atas air. Elemen persegi yang mengambang di atas air juga melambangkan bersatunya jagad besar dan jagad kecil. Elemen air selain mendukung penghawaan pasif, juga menghasilkan bunyi gemericik yang menenangkan pikiran.
Ruang-ruang latihan kemudian disusun membentuk sebuah mandala, dimana ruang meditasi (dhyana) berada di tengah (Gambar 10). Mandala melambangkan keseimbangan, dan ruang meditasi yang menjadi pusat dari mandala melambangkan tujuan akhir dari pembelajaran yoga. Apabila anga yang terakhir telah dijalankan, maka seseorang akan mencapai keseimbangan dalam hidup.

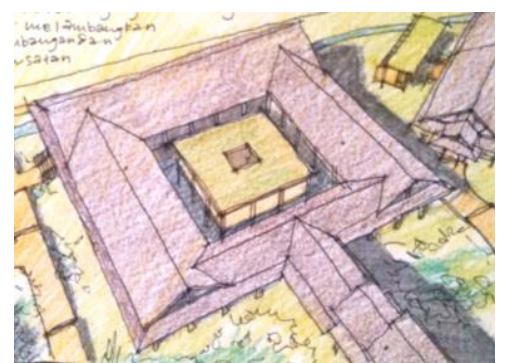

Gambar 10. Konfigurasi Mandala Pada Gedung Utama.

Secara umum, sistem struktur yang digunakan adalah sistem konstruksi panggung (stilt construction) (Gambar 11). Sistem struktur ini digunakan karena beberapa alasan:

1. Tapak memiliki kontur yang tidak rata. Dengan sistem struktur panggung, tidak terlalu banyak perubahan permukaan tapak (cut and fill) yang harus dilakukan.

2. Sistem struktur panggung dapat memberi ventilasi bagian bawah bangunan. Udara dingin dapat dengan bebas berhembus di bawah bangunan sebagai penghawaan alami.

3. Struktur yang dinaikkan dari permukaan tanah melindungi struktur utama dari rayap dan hama yang lain.

4. Struktur panggung dapat melindungi dari banjir dan tanah longsor. Dengan permukaan tanah yang dibiarkan terekspos, 
air hujan dapat dengan mudah diserap sehingga menghindarkan genangan yang dapat memicu terjadinya tanah lonsor.

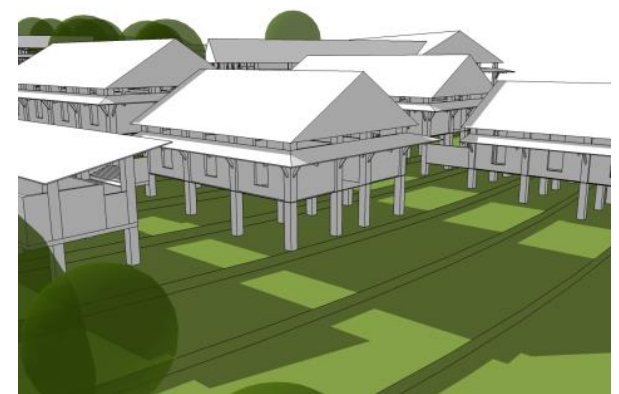

Gambar 11. Penerapan Sistem Struktur Panggung.

Material yang digunakan adalah gabungan dari material beton dan kayu. Secara umum, material yang digunakan untuk sub-struktur dan super-struktur adalah glue laminated timber (glue-lam). Glue-lam terbuat dari serpihan kayu yang dikompresi dan direkatkan dengan epoksi sehingga menghasilkan material yang lebih kuat secara struktural.

Untuk melindungi struktur kayu dari kelembaban permukaan tanah dan hama pengganggu seperti rayap dan pengerat yang lain, pondasi dibuat dari material beton. Pondasi beton tersebut kemudian diikat dengan balok pengikat pada bawah permukaan tanah untuk mengurahi structural distress. Material untuk dinding terbatas adalah drywall dari bahan gipsum. Material drywall gipsum digunakan karena lebih cepat dalam proses pemasangan.

Ashtāinga Yoga Ashram dirancang dengan tampilan yang selaras dengan bangunanbangunan yang ada di sekitarnya. Bangunan di sekitar ashram kebanyakan berupa rumah warga yang bergaya tradisional. Oleh karena itu, pemilihan material dan bentuk bangunan ashram mengikuti tampilan bangunanbangunan di sekitarnya, yaitu menggunakan material lokal dan tampilan struktur yang sederhana.

Tapak berada pada daerah dengan curah hujan yang cukup tinggi. Oleh karena itu, konsep perancangan ashram dirumuskan untuk merespon curah hujan yang tinggi tersebut. Atap bangunan dirancang dengan kemiringan yang curam $\left(20^{\circ}-30^{\circ}\right)$ agar air hujan dapat dengan cepat turun. Air hujan kemudian di tampung di talang dan dialirkan ke bak penampungan untuk dimanfaatkan kembali. Kolam-kolam dirancang selain sebagai elemen dekoratif lanskap, juga sebagai tempat penampungan air hujan (Gambar 12). Rancangan tritisan dengan ukuran yang optimal. Ukuran tritisan yang cukup lebar (1,5-2 meter) dapat melindungi ruang-ruang semi terbuka dari curahan air hujan yang deras.

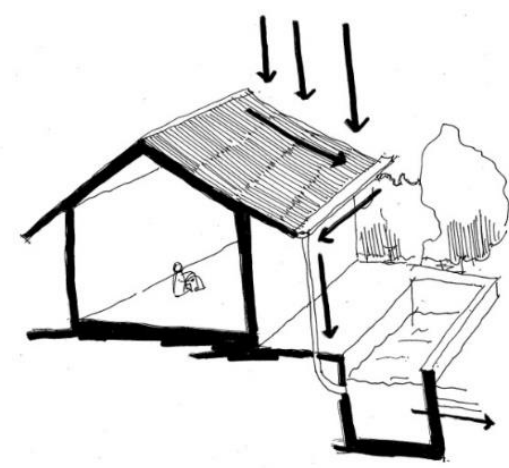

Gambar 12. Skema Pengaliran Air Hujan.

Suhu udara yang cukup rendah dapat dimanfaatkan pada siang hari. Ruang-ruang yang banyak digunakan pada siang hari didesain terbuka agar tidak udara dingin dapat dengan leluasa masuk (Gambar 13). Ruangan tidak memerlukan pendingin udara. Ruangruang yang digunakan pada malam hari seperti ruang meditasi dan kamar tidur didesain lebih tertutup dengan material yang tebal untuk menahan dinginnya suhu dari luar ruangan. Ruang ruang yang tertutup diberi lubanglubang agar udara dapat tetap dengan leluasa bergerak.

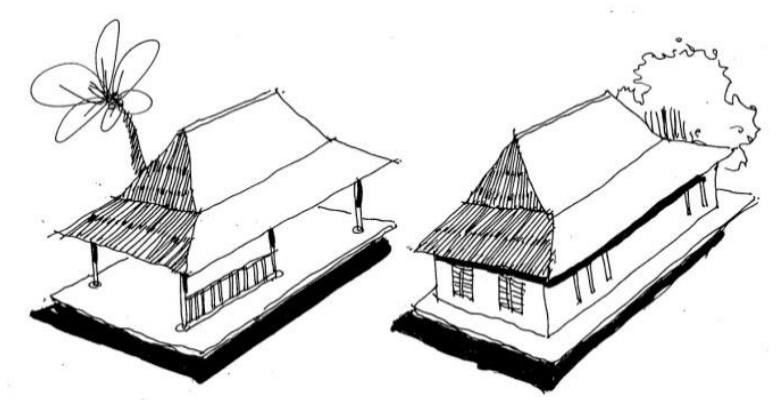

Gambar 13. Perbedaan Tingkat Bukaan Ruang. 
Tiupan angin dengan kecepatan sedang dimanfaatkan untuk ventilasi silang (Gambar 14). Terdapat bukaan-bukaan yang berorientasi timur-barat, menyesuaikan arah angin yang bertiup dari gunung Lawu (Gambar 15). Bukaan-bukaan dapat dibuka-tutup dan disesuaikan dengan kecepatan angin. Pada bagian-bagian tertentu, ditanam vegetasi buffer yang menyaring angin yang terlalu kencang.

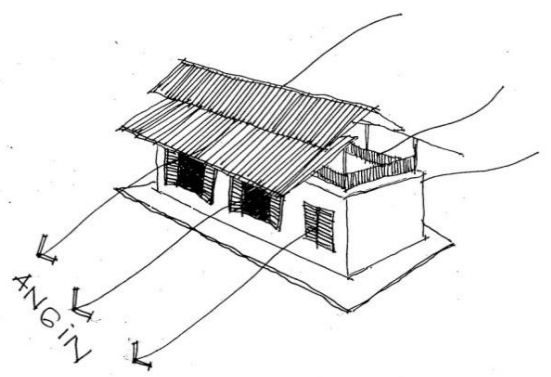

Gambar 14. Ventilasi Silang Pada Bangunan.

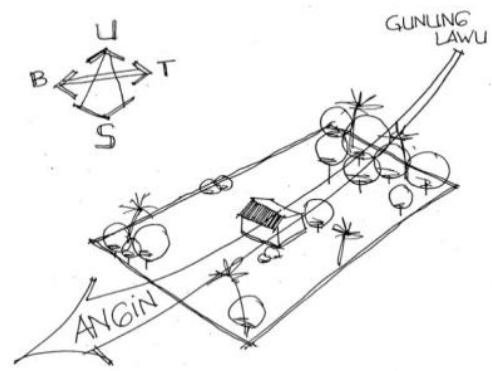

Gambar 15. Orientasi Bangunan Merespon Aliran Angin.

Pada bagian timur-barat bangunan, dipasang tritisan yang lebar untuk melindungi dari sinar matahari. Tritisan pada bagian barat bangunan lebih lebar karena sinar matahari sore lebih panas dan menyengat. Selain itu, pada beberapa bagian komplek ditanami vegetasi naung yang melindungi bagian dinaungi dari terik matahari. Atap yang digunakan dirancang secara berlapis yang berperan sebagai insulasi panas (Gambar 16). Selain itu, bahan penutup atap menggunakan material yang tebal agar panas matahari dapat tertahan.

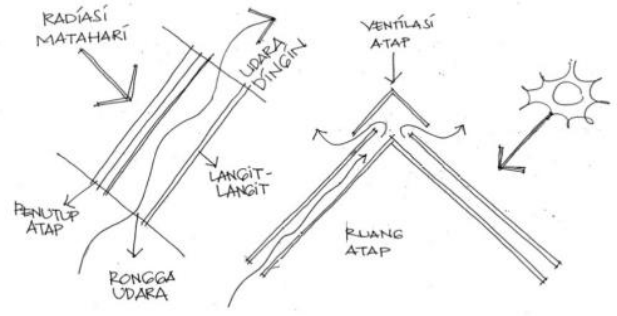

Gambar 16. Rongga Udara Pada Atap.

\section{KESIMPULAN}

Ashtāngā Yoga Ashram adalah wadah untuk mempelajari ashtāingā yoga, dan berada di Kabupaten Karanganyar. Ashtāingā Yoga Ashram diperlukan karena masih jarangnya wadah khusus untuk mempelajari ashtāing $\bar{a}$ yoga di Indonesia yang memiliki karakter sebuah ashram/retret. Spesifikasi dan karakteristik ruang yang diciptakan pada area untuk setiap laku dalam ashtāing $\bar{a}$ yoga dirancang secara khas untuk menciptakan suasana yang mendukung laku yang dilakukan. Pengguna Ashtāngna Yoga Ashram adalah para pelaku dan guru ashtāingā yoga, baik dari dalam maupun luar negeri.

Untuk mencapai tujuan desain dan menjawab persoalan desain yaitu menciptakan suasana khusus pada wadah untuk setiap àngā, maka sasaran konsep perencanaan arsitektur didasarkan pada karakter setiap āngā tersebut. Konsep wadah $\bar{a} \dot{n} g \bar{a}$ yang pertama, yama atau pengendalian diri, untuk menciptakan atmosfer yang mendukung interaksi positif antar sesama pelaku yoga. Konsep wadah āngā yang kedua, niyama atau hubungan vertikal dengan Tuhan dan alam semesta. Konsep wadah āingà yang ketiga, āsana atau pengaturan postur tubuh, untuk menciptakan atmosfer yang mendukung kegiatan olah tubuh yang optimal yang menenangkan pikiran.

Konsep wadah ànga yang keempat, prāṇayāma atau pengaturan napas, untuk menciptakan atmosfer yang menenangkan pikiran dan kelegaan ketika mengatur prānā. Konsep wadah $\bar{a} \dot{n} g \bar{a}$ yang kelima, pratyāhāra atau pelepasan hasrat duniawi, untuk menciptakan atmosfer yang mendukung pengendalian panca indera. Konsep wadah $\bar{a} \dot{n} g \bar{a}$ yang keenam, dhāraṇa atau konsentrasi, 
untuk menciptakan atmosfer tenang yang mendukung pengendalian pikiran. Konsep wadah āng $\bar{a}$ yang ketujuh, dhyāna atau kontemplasi, untuk menciptakan atmosfer yang mendukung kegiatan meditatif dengan tujuan menyatukan badan, pikiran, dan lingkungan sekitar. Seluruh wadah latihan yoga yang spesifik kemudian disusun dalam sekuen ruang yang didasarkan pada tingkat kesakralan dari laku yang dilakukan.

\section{REFERENSI}

Krishna, Anand. 2015. Yoga Sutra Patanjali Bagi Orang Modern. Jakarta: Gramedia.

Swahananda, Swami. 1990. Monasteries in South Asia. Los Angeles: Vedanta Press.

White, David Gordon. 2014. The Yoga Sutra of Patanjali: A Biography. Princeton: Princeton University Press. 